\title{
THE EFFECT OF FACILITIES AND SERVICE QUALITY ON CUSTOMER SATISFACTION OF GAS STATION IN SETU BEKASI, WEST JAVA
}

\author{
Anjas Riseetyawan $^{1 *}$, Sularto $^{2}$, Agusti Eviana Sari ${ }^{3}$ Badrunsyah $^{4}$ \\ $1,2,3,4$ \\ Universitas Respati Indonesia \\ E-mail: ${ }^{1)}$ amelaprina@gmail.com, ${ }^{2)}$ advisorhr@yahoo.com
}

\begin{abstract}
This study aims to determine the effect of the effect of facilities and service quality on customer satisfaction of gas station in Setu Bekasi, West Java. This research is quantitative research. The data analysis method used is Structural Equation Modeling-Partial Least Square (SEM-PLS) Smart PLS software version 3. The population in this study were gas station customers 3417308 Setu Bekasi, West Java, which according to Non-Probability Sampling with the Accidental Sampling method, resulting total sample of 353 respondents. The testing stages are validity test, reliability test, inner model includes convergent validity, discriminant validity, composite validity, Cronbach's alpha, outer model includes path coefficient test and hypothesis testing. The finding reveals that the facility has a positive and significant direct effect on Customer Satisfaction, the service quality has a direct and significant positive effect on Customer Satisfaction, and the facility has a direct positive and significant effect on Service Quality. Meanwhile, the facilities and service quality have a positive and significant indirect effect on customer satisfaction. From the results of these studies, it can be concluded that the facilities and service quality have an indirect effect on customer satisfaction, but with the facilities and service quality in accordance with what customers expect, it can create and increase customer satisfaction.
\end{abstract}

Keywords: Facilities, Service Quality, Consumer Satisfaction

\section{INTRODUCTION}

Indonesian competition has becoming more intense, particularly in the business sector. A growing number of firms are therefore emerging to build service as well as goods-related businesses. Where entrepreneurs want to meet the needs and desires of customers and the expectations that customers desire so that customers remain loyal to using services and goods that will be used as profits for the company.

Entrepreneurs must maintain the individual demands that are used as business possibilities to manufacture and use goods or services in which details of sales or transactions between sellers and buyers are available (Sullah et al., 2021). As a result, the company's product line is broad, and the corporation intends for the goods or services that will be used by customers to remain superior in comparison to those provided by other companies or competitors (Mangkunegara \& Prabu, 2005). Marketing strategy is a type of marketing thinking in which a corporate organization seeks to add value and profit to its relationship with customers and clients (Hastuti et al., 2020).

Fuel is one of several items that can be used as a business opportunity. Fuel is something that society requires. Along with developments in knowledge and technology, fuel is one of the key demands of the community to support numerous daily activities. Every day, the usage 
of fuel is required, as is the use of a vehicle in general. Land, sea, and air transportation are all available in Indonesia. Motorbikes, vehicles, trucks, buses, and other modes of land transportation are increasingly being developed in Indonesia and as a result, the need for fuel is rising. PT Pertamina (Persero) is the Indonesian company that manufactures and distributes fuel.

Independent international auditors that conduct monthly monitoring of certified gas stations to ensure continuous application of service standards. As a consequence, gas station or Public Fuel Filling Stations (SPBU) are government and commercial parties that collaborate with Pertamina to market the items they manufacture. Fuel products that want to be sold are not only assured in terms of quality, but also of stock availability at gas stations that are adapted to consumer needs on a daily basis and are overseen by Pertamina. Because of the large number of gas stations in Indonesia, creating services and facilities at gas stations is a difficult challenge. The Pertamina PASTI PAS gas station is one of the breakthroughs since it is a gas station that has been certified to satisfy the highest service requirements.

In addition, customers do not only want the quality and quantity of fuel with guaranteed quality and service according to applicable operational standards, but the facilities and infrastructure available at gas stations such as: prayer rooms, toilets for men and women, bright stores. With a complete facility, it will be one of the added values for the company, therefore the gas station must improve the existing facilities at the gas station. The company not only completes the existing facilities at the gas station, but the company must also pay attention to the quality of service.

Service quality is one of the basic ways of business that produces goods or services that make it easy for people to meet their needs and interests. Through good, fast, thorough and accurate service as well as applying " $3 \mathrm{~S}$ (smile, greeting and greeting)" that apply at gas stations, it will create customer loyalty and satisfaction for gas stations who want to make customers always use the goods or services at the gas station.

Satisfaction is a person's feelings of pleasure or disappointment that arise when comparing performance with the expected results. If the performance is below expectations, the customer is not satisfied. If performance meets expectations, customers will be satisfied. If performance exceeds expectations, the customer will be satisfied or happy.

One of the goals of gas stations is to meet consumer needs and achieve customer satisfaction and reduce customer complaints. So that gas stations are able to compete and achieve their goals by completing facilities at gas stations, creating the best quality service by implementing $3 \mathrm{~S}$ in accordance with operational standards applicable at gas stations and being able to provide good service satisfaction to the surrounding community. By implementing it all, customers will remain loyal to use the goods or services available at gas stations.

\section{LITERATURE REVIEW}

\subsection{Facility}

According to Tjiptono (2007) Facilities is included in physical evidence of an organization, which also includes the organization's physical facilities (servicescape) and other types of physical evidence. Further, Tjiptono (2007) explain that the design and layout of service facilities is closely related to the formation of customer expectations. A number 


\section{JOURNAL OF MANAGEMENT, ACCOUNTING, GENERAL FINANCE AND INTERNATIONAL ECONOMIC ISSUES (MARGINAL) \\ VOLUME 1 ISSUE 2 (2022)}

of types of perception services formed from communication between customers and facilities affect the quality of these services in the eyes of customers. According to Tjiptono (2007) facilities are considered acceptable and adequate from several facilities indicators, namely:

1) Spatial considerations (according to standards), namely aspects such as proportions, textures, colors and others are considered, combined and developed to provoke intellectual and emotional responses from the user or people who see them.

2) Spatial planning, which includes interior and architectural planning, such as the placement of furniture and fixtures in the room, circulation flow design and others.

3) Adequate equipment/furniture is equipment or furniture that provides comfort as a supporting infrastructure for users.

4) Lighting and color, namely the color of the room coloring and lighting settings according to the nature of the activities carried out indoors or outdoors.

5) The supporting element is that the main facilities are incomplete without other supporting facilities such as: places of worship, toilets, parking lots, places to eat and drink, as well as large areas that are always considered for safety.

\subsection{Quality Of Service}

Service quality can be defined as how far the difference between the reality and expectations of customers for the services they receive (Sullah et al., 2021). Service quality can be identified by comparing customer perceptions of the services they actually receive. According to Arianto (2018) service quality can be defined as focusing on meeting needs and requirements, as well as on timing to meet customer expectations. Services apply to all types of services provided by the company. Furthermore, according to Tjiptono \& Chandra (2011) service quality as a measure of how well the level of service provided is able to match customer expectations.

Meanwhile, according to Fandy (2007), service quality is the level of excellence expected and control over the level of excellence to meet customer desires. Based on the opinion above, it can be concluded that there are main factors that affect the quality of service, namely the expected service and the perceived service. If the perceived service is in accordance with what is expected, then the quality of the service will be perceived as good or positive.

According to Harfika \& Abdullah (2017) there are five service quality indicators, namely:

1) Tangible/Direct Evidence

Tangibles are real evidence of the care and attention given by service providers to consumers.

2) Reliability

Reliability is the company's ability to carry out services in accordance with what has been promised in a timely manner.

3) Responsiveness

Responsiveness is the company's ability carried out by employees directly to provide services quickly and responsively.

4) Assurance

Assurance is the knowledge and behavior of employees to build trust and confidence in consumers in consuming the services offered.

5) Empathy/Empathy 
Empathy is the company's ability to be carried out directly by employees to give attention to individual consumers.

\subsection{Customer Satisfaction}

Actually, customer satisfaction is still abstract. Achievement of satisfaction can be a simple concept, or complex and complicated. In this case, the role of each individual in the service is very important and influences the satisfaction that is formed. To be able to know the level of customer satisfaction better, it is necessary to understand the causes of satisfaction. Not only are customers more dissatisfied with services than goods, but they also rarely complain, one reason being that they are also involved in the service creation process. Customer satisfaction is a comparison of the quality of service received by consumers to the level of service expected by customers; if the quality received by customers is less than expected, then there is dissatisfaction. On the other hand, if the consumer feels as expected, he or she will be satisfied, and if the quality of service exceeds expectations, the customer will be extremely satisfied.

According to marketing experts, Philip \& Kevin (2007) explains that consumer satisfaction is a person's feelings of pleasure and disappointment that arise after comparing their perceptions or impressions of the performance (results) of a product and their expectations. Customer satisfaction is an important approach to be able to maintain, so without customer satisfaction, the company is difficult to survive in the face of competitive competition. If the customer is not satisfied, it will be easy to move to another similar company.

According to Taufik (2017) there are four factors that influence customer satisfaction, namely:

1) Product quality, customers will be satisfied if the products used are of good quality.

2) Price, customers are very sensitive, usually low prices are an important source of satisfaction because customers will get high value for money

3) Service quality, satisfaction with service quality is usually difficult to imitate. Service quality is a driver that has many dimensions, one of which is popular is servqual

4) Cost and convenience, customers will be more satisfied if it is relatively easy, comfortable, and efficient in getting a product or service

5) Emotional Factors, customers will feel satisfied (proud) because of the emotional value provided by the brand of the product.

\section{RESEARCH METHOD}

This research is a type of quantitative research. The data analysis method used Structural Equation Modeling-Partial Least Square (SEM-PLS) Smart PLS software version 3. The population in this study were gas station customers 3417308 of Setu Bekasi, West Java, which according to pre-study observation data amounted to 353 people. The sample is Non Probability Sampling with the Accidental Sampling method, with a total sample of 353 respondents. Meanwhile, the testing stages are validity test, reliability test, inner model includes convergent validity, discriminant validity, composite validity, Cronbach's alpha, while outer model includes path coefficient test and hypothesis testing. 


\section{JOURNAL OF MANAGEMENT, ACCOUNTING, GENERAL \\ FINANCE AND INTERNATIONAL ECONOMIC ISSUES \\ (MARGINAL) \\ VOLUME 1 ISSUE 2 (2022)}

\section{RESULT AND DISCUSSION}

\subsection{Result Research}

\subsubsection{Validity Test}

Based on the research that has been done, the results of the can be seen in the following table.

Table 1 Validity Test of Facility (X1), Service Quality (X2) and Customer Satisfaction (Y)

\begin{tabular}{cccc}
\hline Indicator & $\mathbf{r}$-statistic & $\mathbf{r}$-table & Description \\
\hline $\mathrm{X} 1.1$ & 0.942 & 0.195 & Valid \\
X1.2 & 0.910 & 0.195 & Valid \\
X1.3 & 0.893 & 0.195 & Valid \\
X1.4 & 0.561 & 0.195 & Valid \\
X1.5 & 0.928 & 0.195 & Valid \\
\hline X2.1 & 0.686 & 0.195 & Valid \\
X2.2 & 0.831 & 0.195 & Valid \\
X2.3 & 0.766 & 0.195 & Valid \\
X2.4 & 0.665 & 0.195 & Valid \\
X2.5 & 0.592 & 0.195 & Valid \\
\hline Y1 & 0.831 & 0.195 & Valid \\
Y2 & 0.937 & 0.195 & Valid \\
Y3 & 0.927 & 0.195 & Valid \\
Y4 & 0.595 & 0.195 & Valid \\
Y5 & 0.668 & 0.195 & Valid \\
\hline
\end{tabular}

4.1.2. Reliability Test

Table 2 Reliability Test Results

\begin{tabular}{cccc}
\hline Variable & $\begin{array}{c}\text { Cronbach } \\
\text { Alpha }\end{array}$ & $\begin{array}{c}\text { Critical } \\
\text { Value }\end{array}$ & Description \\
\hline Facility & 0.903 & 0.600 & Reliable \\
Service Quality & 0.762 & 0.600 & Reliable \\
Customer & 0.856 & 0.600 & Reliable \\
Satisfaction & & & \\
\hline
\end{tabular}

\subsubsection{Inner Model}

a. Convergent Validity

Table 3 Outer Loading

\begin{tabular}{ccc}
\hline Variable & Indicator & Outer loading \\
\hline Facilities (X1) & X1.1 & 0.942 \\
& X1.2 & 0.910 \\
& X1.3 & 0.893 \\
& X1.4 & 0.561 \\
Quality of Service (X2) & X2.1 & 0.928 \\
& X2.2 & 0.686 \\
& & 0.831
\end{tabular}




\begin{tabular}{ccc} 
& X2.3 & 0.766 \\
& X2.4 & 0.665 \\
& X2.5 & 0.592 \\
Customer Satisfaction & Y1 & 0.831 \\
(Y) & & \\
& Y2 & 0.937 \\
& Y3 & 0.927 \\
& Y4 & 0.595 \\
& Y5 & 0.668 \\
\hline
\end{tabular}

b. Discriminant Validity

Table 4 Cross Loading Results

\begin{tabular}{cccc}
\hline Indicator & $\begin{array}{c}\text { Facilities } \\
\text { (X1) }\end{array}$ & $\begin{array}{c}\text { Quality of } \\
\text { Service } \\
\text { (X2) }\end{array}$ & $\begin{array}{c}\text { Customer } \\
\text { Satisfaction(Y) }\end{array}$ \\
\hline X1.1 & 0.942 & 0.561 & 0.654 \\
X1.2 & 0.910 & 0.559 & 0.570 \\
X1.3 & 0.893 & 0.515 & 0.563 \\
X1.4 & 0.561 & 0.530 & 0.288 \\
X1.5 & 0.928 & 0.544 & 0.629 \\
X2.1 & 0.483 & 0.686 & 0.327 \\
X2.2 & 0.704 & 0.831 & 0.658 \\
X2.3 & 0.398 & 0.766 & 0.469 \\
X2.4 & 0.256 & 0.665 & 0.388 \\
X2.5 & 0.209 & 0.592 & 0.483 \\
Y1 & 0.385 & 0.576 & 0.831 \\
Y2 & 0.424 & 0.546 & 0.937 \\
Y3 & 0.415 & 0.544 & 0.927 \\
Y4 & 0.198 & 0.465 & 0.595 \\
Y5 & 0.888 & 0.526 & 0.668 \\
\hline
\end{tabular}

Table 5 AVE value

\begin{tabular}{cc}
\hline Variable & AVE \\
\hline Facilities (X1) & 0.738 \\
Quality of Service (X2) & 0.508 \\
Customer Satisfaction (Y) & 0.645 \\
\hline
\end{tabular}

c. Composite Reliability

Table 6 Composite Reliability Value

\begin{tabular}{cc}
\hline Variable & Composite Reliability \\
\hline Facilities (X1) & 0.932 \\
Quality of Service (X2) & 0.836
\end{tabular}




\section{JOURNAL OF MANAGEMENT, ACCOUNTING, GENERAL FINANCE AND INTERNATIONAL ECONOMIC ISSUES \\ (MARGINAL) \\ VOLUME 1 ISSUE 2 (2022)}

Customer Satisfaction (Y)

0.898

d. Cronbach's Alpha

Table 7 Cronbach's Alpha value

\begin{tabular}{cc}
\hline Variable & Cronbach's Alpha \\
\hline Facilities (X1) & 0.903 \\
Quality of Service (X2) & 0.762 \\
Customer Satisfaction (Y) & 0.856 \\
\hline
\end{tabular}

\subsubsection{Outer Model}

a. Path Coefficient Test

Table 8 R-Square

\begin{tabular}{cc}
\hline Variable R-Square Value & R-Square Value \\
\hline Quality of Service (X2) & 0.654 \\
Customer Satisfaction (Y) & 0.718 \\
\hline
\end{tabular}

b. Hypothesis testing

Table 9 Path Coefficient

\begin{tabular}{|c|c|c|c|c|}
\hline The effect & $\begin{array}{l}\text { Original } \\
\text { Sample }\end{array}$ & T-Statistics & P. Value & Results \\
\hline $\begin{array}{l}\text { Facilities }=>\text { Customer } \\
\text { Satisfaction }\end{array}$ & 0.365 & 4.489 & 0.000 & Accepted \\
\hline $\begin{array}{l}\text { Service Quality => Customer } \\
\text { Satisfaction }\end{array}$ & 0.446 & 5.561 & 0.000 & Accepted \\
\hline Facilities $=>$ Quality of Service & 0.628 & 15,720 & 0.000 & Accepted \\
\hline $\begin{array}{l}\text { Facilities }=>\text { Service Quality } \\
=>\text { Customer Satisfaction }\end{array}$ & 0.280 & 5.628 & 0.000 & Accepted \\
\hline
\end{tabular}

\subsection{Discussion}

\subsubsection{Knowledge toward Saving Interests}

Based on the results of the research that has been described above, the results obtained are that there is a positive influence between knowledge and interest in saving. This is evidenced by the Knowledge coefficient value in the regression test of 0.450 , which means that if knowledge increases by one point, the interest in saving will increase by 0.450 at a constant of 6.775. In addition, based on the results of the partial significance test or t test, it is obtained $\mathrm{T}_{\text {statistic }}$ of 6.692 , it can be seen that $\mathrm{T}_{\text {statistic }}$ it is greater than $\mathrm{T}_{\text {table }} 1.972$ with a significance level of $0.000<0.05$ which states that knowledge partially has a positive and significant effect on saving interest.

\subsubsection{The Effect of Facilities on Customer Satisfaction}

The first hypothesis examines whether the facility has a positive effect on customer satisfaction. The test results show the value of the Facility beta coefficient on Customer Satisfaction is 0,365 and the t-statistic is 4,489 . From these results, it is stated that the $t$ statistic is significant. Because $>1,96$ with $\mathrm{p}$-value, so that the first hypothesis is accepted. This proves that the facility has a positive effect on customer satisfaction. 


\subsubsection{The Effect of Service Quality on Customer Satisfaction}

The second hypothesis examines whether Service Quality has a positive effect on Customer Satisfaction. The test results show the value of the beta coefficient of Service Quality on Customer Satisfaction is 0,446 and the t-statistic is 5,561. From these results, it is stated that the t-statistic is significant. Because $>1,96$ with p-value, so that the second hypothesis is accepted. This proves that service quality has a positive effect on customer satisfaction.

\subsubsection{Influence of Facilities on Service Quality}

The third hypothesis examines whether the facilities have a positive effect on service quality. The test results show the value of the Facility's beta coefficient on Service Quality is 0,628 and the t-statistic is 15,720 . From these results, it is stated that the t-statistic is significant. Because $>1,96$ with p-value, so that the first hypothesis is accepted. This proves that the Facility has a positive effect on Service Quality.

\subsubsection{The Effect of Facilities and Service Quality on Customer Satisfaction}

The fourth hypothesis examines whether Facilities and Service Quality positively affect customer satisfaction. The test results show the beta coefficient value of Facilities and Service Quality on Customer Satisfaction is 0,654. This shows that the effect of Facilities and Service Quality, to Customer Satisfaction by $65,4 \%$. The results of the hypothesis state that Facilities and Service Quality have an indirect effect on Customer Satisfaction, which is proven true or $\mathrm{H} 4$ is accepted.

\section{CONCLUSION}

This study aims to determine the effect of facilities and service quality on customer satisfaction of gas station in Setu Bekasi, West Java. According to the findings, it can be concluded that:

1. The results of data analysis indicate that the facility has a positive and significant direct effect on customer satisfaction. It is proven by the results of the hypothesis that the facility variable on customer satisfaction is significant. This means that if the facilities provided at the gas station are as expected by the customer, the customer will feel satisfied and happy, so that the customer will remain loyal to the gas station. Vice versa, if the available facilities are not in accordance with what the customer expects, then the customer does not have a sense of satisfaction and pleasure with the facilities provided at the gas station.

2. The results of data analysis show that service quality has a direct and significant positive effect on customer satisfaction. This is known from the results of the hypothesis between service quality variables on customer satisfaction. Therefore, it can be interpreted that service quality has an important role in increasing customer satisfaction. With good service quality, it will have an effect on increasing customer satisfaction. On the other hand, if the quality of service is low, it will have an impact on decreasing customer satisfaction ratings for gas stations and will also cause a decrease in sales. 


\section{JOURNAL OF MANAGEMENT, ACCOUNTING, GENERAL FINANCE AND INTERNATIONAL ECONOMIC ISSUES (MARGINAL) \\ VOLUME 1 ISSUE 2 (2022)}

3. The results of data analysis indicate that the facility has a direct positive and significant effect on Service Quality. This is known from the results of the hypothesis between the variables of Facility and Service Quality. Therefore, it can be concluded that facilities are very important as a basis in improving the quality of service at gas stations. The more the facilities provided are in accordance with what the customer expects and the better the quality of service received by the customer, the customer will continue to repurchase the fuel product provided at the gas station and the customer will be loyal to the company.

4. The results of data analysis indicate that the facilities and service quality have a positive and significant indirect effect on customer satisfaction. Hence, it can be concluded that the facilities and service quality have an indirect effect on customer satisfaction, but with the facilities and service quality in accordance with what customers expect, it can create and increase customer satisfaction.

\section{Suggestions}

From the conclusions above, the researchers suggest several aspect, such as :

1) In accordance with the research above, the indicator of lighting and color in the Facility variable gets the lowest value even though the results are still positive, this shows that the gas station 3417308 should pay more attention to the level of lighting and color at the facilities at the gas station.

2) In accordance with the research above that the empathy indicator in the expansion of the Service Quality variable line gets the lowest value even though the results are still positive, this shows that the Setu Bekasi gas station should be more active in providing services to customers, especially for fuel refueling officers to be more active in asking customers what products they want to buy, and how much. So that with the more active officers with customers in serving, customers will feel satisfied and happy with the services provided by gas station officers to customers.

3) In accordance with the research above, the lighting and color indicators in the Facility variable get the lowest value even though the result is still positive, this shows that the SPBU 3417308 Setu Bekasi pays more attention to lighting and color at the gas station and pays more attention to service quality.

4) In accordance with the research above that the cost and convenience indicators in the Customer Satisfaction variable get the lowest value even though the results are still positive, this shows that the 3417308 Setu Bekasi gas station should pay more attention to the product so that the fuel products provided at the gas station are easy to find and the product is in accordance with customer needs so that it can make customers keep making repeat purchases at SPBU 3417308 Setu Bekasi.

\section{REFERENCES}

Arianto, N. (2018). Pengaruh Kualitas Pelayanan Terhadap Kepuasan Dan Loyalitas Pengunjung Dalam Menggunakan Jasa Hotel Rizen Kedaton Bogor. Jurnal Pemasaran Kompetitif, 1(2).

Fandy, T. (2007). Strategi Pemasaran, edisi kedua. Yogyakarta: Penerbit Andi. 
Harfika, J., \& Abdullah, N. (2017). Pengaruh Kualitas Pelayanan Dan Fasilitas Terhadap Kepuasan Pasien Pada Rumah Sakit Umum Kabupaten Aceh Barat Daya. BALANCE: Economic, Business, Management and Accounting Journal, 14(01).

Hastuti, P., Nurofik, A., Purnomo, A., Hasibuan, A., Aribowo, H., Faried, A. I., Tasnim, Ta., Sudarso, A., Soetijono, I. K., \& Saputra, D. H. (2020). Kewirausahaan dan UMKM. Yayasan Kita Menulis.

Mangkunegara, A. P., \& Prabu, A. (2005). Evaluasi kinerja sumber daya manusia. Bandung: Refika Aditama.

Philip, K., \& Kevin, K. (2007). Manajemen Pemasaran Edisi 12. Jilid Pertama dan Kedua. Jakarta: PT. Indeks.

Sulasih, S., Manullang, S. O., Purba, B., Mardia, M., Purba, P. B., Mistriani, N., Simarmata, J., Dewi, I. K., Hasdiana, S., \& Irdawati, I. (2021). Studi Kelayakan Bisnis. Yayasan Kita Menulis.

Taufik, A. I. (2017). Evaluasi Regulasi Dalam Menciptakan Kemudahan Berusaha Bagi UMKM. Jurnal Rechts Vinding: Media Pembinaan Hukum Nasional, 6(3), 369-386.

Tjiptono, F. (2007). Strategi Pemasaran Edisi ke dua, penerbit Andi. Yogyakarta.

Tjiptono, F., \& Chandra, G. (2011). Service, Quality \& Satisfaction Edisi 3. Yogyakarta: Andi, 1 . 